\title{
RENDSZEREK, SZABÁLYOZÁSOK A TERMÉSZETBEN ÉS A TÁRSADALOMBAN
}

\section{Szerző:}

Ujfaludi László (professor emeritus)

Eszterházy Károly Egyetem

A szerző e-mail címe:

ujfaludi.laszlo@gmail.com

\section{Lektorok:}

\author{
Borbélyné Bacsó Viktória (PhD) \\ Medgyessy Ferenc Gimnázium \\ és Művészeti Szakgimnázium \\ Mező Ferenc (PhD) \\ Eszterházy Károly Egyetem
}

és további két anonim lektor...

\begin{abstract}
Absztrakt
Jelen cikk a rendszerek jellemzőire összpontosít, és néhány példát mutat be a rendszerek megnyilvánulásaira és mechanizmusaira az ember, a természet, a környezet, a társadalom, a képzőművészet, a természettudomány szempontjából.
\end{abstract}

Kulcsszavak: rendszer, tudomány, társadalom, múvészet

Diszciplína: interdiszciplináris

\section{Abstract}

SYSTEMS, REGULATIONS IN NATURE AND SOCIETY

The present paper focuses on the characteristics of systems and shows some examples of systems manifestations and mechanisms from the aspects of man, nature, environment, society, fine arts, natural sciences.

Keywords: system, science, society, art

Discipline: interdisciplinary

Ujfaludi László (2021): Rendszerek, szabályozások a természetben és a társadalomban. OxIPO - interdiszciplináris tudományos folyóirat, 2021/2, 9-23.

doi: 10.35405/OXIPO.2021.2.9 
A rendszer általánosan ismert és kiterjedten használt fogalom, például a szoba, ahol tartózkodunk, rendelkezik fütési-, esetleg légkondicionáló rendszerrel. Amikor utazunk, a közlekedési rendszert terheljük. Szervezetünkben működik a vérkeringési- és emésztőrendszer, amelyek működését az idegrendszer szabályozza. Mit is jelent hát a rendszer fogalom? Hogyan lehetséges, hogy ennyiféle, egymástól különböző dologra ugyanazt a szót használjuk?

A rendszer fogalmát talán az alábbi definíció fejezi ki a legáltaláno-sabban: „Egymással meghatározott vi-szonyban lévő elemek egységes egészet képező halmaza. Alkotórészeinek kapcso-lódási módja adja a rendszer szerkezetét. A rendszerek általában alrendszerekre bonthatók. A rendszer, mint egész olyan integratív sajátosságokkal is rendelkezik, amelyeket alkotórészei (alrendszerei, elemei) nem mutatnak." (Bárczi és Országh, 1989)

Minden rendszerre jellemzők továbbá az alábbi tulajdonságok:

1. elemekből, részekből áll, amelyek között funkcionális kapcsolat van;

2. szerkezet, szervezettség és az alkotórészek hierarchiája jellemzi;

3. múködése során anyag- és energiaáramlás történik;

4. magasabb szervezettségű rendszereknél információáramlás is történik;

5. az anyag-, energia- és információáramlás fenntartásához a rendszer energiaforrással rendelkezik.
A rendszerek többsége jól körülhatárolható területen, vagy térfogatban foglal helyet. Ezt valamilyen határolás (más szóval a rendszer pereme) veszi körül, amelyen keresztül a rendszernek a környezettel való kapcsolata lejátszódik. Ilyen rendszer például egy sejt, egy vízgyűjtőterület, egy lombik a laboratóriumban, vagy akár egy felhő az égen.

A határoláson belül helyezkednek el mindenekelőtt a rendszer elemei: atomok, molekulák, homokszemcsék, esőcseppek, vagy akár élőlények: fák, bokrok, nyulak, rókák, emberek stb., amelyek mind térben és időben léteznek. Minden elem rendelkezik egy sor tulajdonsággal és állapottal. Két vagy több elem között, vagy az elemek különböző állapotai között kapcsolatok, összefüggések állnak fenn, amelyek együttesen a rendszer szervezési sémáját alkotják.

A rendszerben bekövetkezett változások egy meghatározott kezdeti állapotból egy végállapotba való átmenet révén mennek végbe, eközben valamilyen útvonalon haladnak végig. A változásoknak ezt a sorozatát a rendszer folyamatainak nevezzük.

\section{A rendszerek irányítása}

Az irányításnak két alaptípusa különböztethető meg (Szűcs, 1999): 1) szabályozás, 2) vezérlés.

Szabályozásnál (1. ábra) a rendszer bemenete és kimenete között a kapcsolatot egy szabályozó elem biztosítja és a kimeneti paraméterek változásától függően 
módosítja a bemenet paramétereit, ezen keresztül a rendszer múködését. Ezt úgy is kifejezhetjük, hogy a kimenet és a bemenet között visszacsatolás van, amely csökkenti a rendszer múködésében a változásokat, ezért negatív visszacsatolásnak nevezik. Két példa a negatív visszacsatolásos szabályozásra: a termosztát és a forgalomirányító rendőr.

1. ábra: Szabályozás (zárt hatásláncú rendszeer-irányitás) $S_{z}=$ szabályozó elem (forrás: a Szerzó)

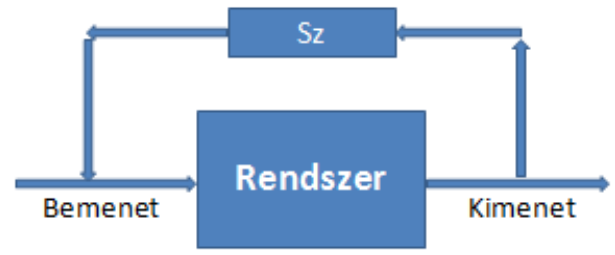

A termosztát (például a villanyvasalóban) a fütőáram ki-bekapcsolása útján szabályozza a vasaló hőmérsékletét úgy, hogy a beállított értéktől az csak kis mértékben térhet el. Az útkereszteződésben álló rendőr figyeli mindkét útirány forgalmát és szükség szerint egyik, vagy másik irányból jövő fogalmat engedi át, ezáltal elkerülhető bármelyik irányban a torlódás.

Vezérlésnél (2. ábra) egy meghatározott program irányítja a rendszer múködését, de nem vesz tudomást a rendszer működésében bekövetkező változásról.
2. ábra: Vezérlés (nyitott hatásláncú rendszerirányitás). Forrás: a Szerzọ"

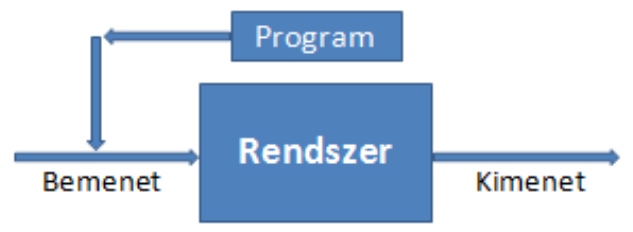

A vezérlésre példa a számítógép-vezérlésű munkagép és a villanyrendőr. Az utóbbi az útkereszteződés forgalmának irányát előre megszabott időrendben váltogatja; ha a forgalomban jelentős változás következik be, nagy forgalmi dugók állhatnak elő. A vezérlés tehát csak addig működik jól, amíg a rendszer múködése nem tér el jelentősen a programban feltételezett működéstől.

Az 1. és a 2. ábra szemlélete alapján a szabályozást és a vezérlést zárt-, illetve nyitott hatásláncú rendszer-irányításnak is nevezik.

\section{Szabályozások a környezeti rendszerekben és az élővilágban}

A természeti folyamatok többségére a szabályozás jellemző, vagyis az események visszahatnak a kiváltó okokra; a változásokat csökkenteni igyekszik a negatív visszacsatolás. Konrad Lorenz (2001) így ír erről: „Minden magas integráltságú szerves rendszer jellemzője az ún. szabályozókörök által történő szabályozás. (...) 
A műszaki tudomány felismerte, hogy egy ilyen (egyébként labilis egyensúlyú) rendszert kiegyenlítetté lehet tenni, ha a körbe beépítünk egy olyan elemet, amely a láncban utána következőre annál gyengébb hatást fejt ki, amennyivel erősebben hat rá az előtte álló. Így létrejön egy szabályozókör, egy 'negatív visszacsatolás'. Ez egyike a műszaki tudomány azon felismeréseinek, amely azelőtt történt, mielőtt a természetkutatók az élővilágban ugyanerre a jelenségre rábukkantak volna. Az élővilágban megszámlálhatatlan szabályozókör működik. Az élet csakis ezek egyidejű múködésével képzelhető el, mert fenntartása nélkülük lehetetlen.”

Az élővilág szabályozó mechanizmusainak tipikus példája az élőlények ún. homeosztázisa. A homeosztázis (v.ö.: Gyulai, 2012) az a képesség, amely lehetővé teszi, hogy a külső környezet paramétereinek viszonylag tág határok közötti változása ellenére az élőlények belső paramétereiket állandó értéken képesek tartani. Az itt érvényesülő tendenciákat a 3. ábrán vázoltuk.

3. ábra: Az élólények homeosztázisa (forrás: a Szerzó)

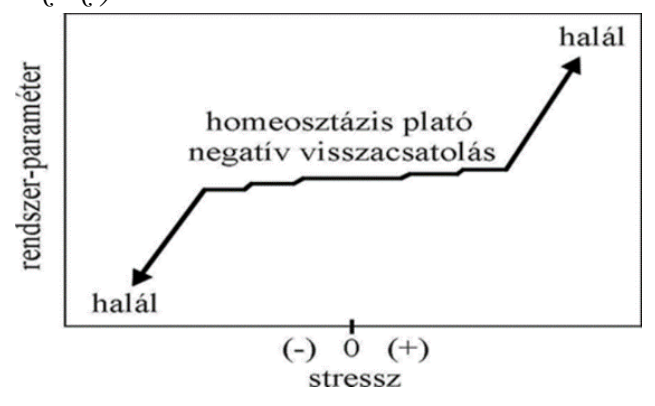

A koordinátarendszer vízszintes tengelyén egy külső stressz (pl. hőmérsékletváltozás, pH-változás, stb.) mértékét, a függőleges tengelyen az élő szervezet egy belső paraméterének (például testhőmérséklet, gyomorsav $\mathrm{pH}$-ja, stb.) változását ábrázoltuk. A stressznek egy bizonyos intervallumában a múködés a homeosztázis platóval jellemezhető. Ebben az esetben a negatív visszacsatolás a stabilitást biztosítani tudja. A stressz szélsőséges értéke (például túlságosan magas, vagy alacsony hőmérséklet) esetén azonban a stabilitás már nem biztosítható tovább, a szervezet működése rohamosan eltávolodik a normálistól; szélsőséges esetekben ez az egyed halálát is jelentheti. Ebben a tartományban a szervezet múködési paraméterei egyre nagyobb mértékben eltérnek az egyensúlyi állapotétól. Az élő szervezetekben a homeosztázis számtalan példáját megtaláljuk. Ide sorolható az emberi szervezet sokféle szabályozása: a testhőmérsékletnek, a vérnyomásnak, a gyomorsav pH-jának, a vér több száz összetevőjének (vércukor, koleszterin, inzulin, amiláz. lipáz, stb.) meghatározott koncentráció tartományban tartása. A betegségek jelentős része éppen ezeknek a szabályozásoknak a hibás működéséből fakad.

Hozzátehetjük, hogy nemcsak az élővilágban múködnek ilyen szabályozókörök. Az élettelen természetben is működnek negatív visszacsatolásos szabályozások. A légköri termosztát ennek egyik példája: a légkör hőmérsékletének növe- 
kedésével nő a párolgás. A vízgőz üvegházhatású gáz: a légkör hőmérsékletét növeli. A pára azonban egy idő után felhőt képez, a felhők visszaverik a beérkező napsugárzás egy részét, ezáltal csökken a levegő hőmérséklete. Hosszabb időtávon az ún. biogeokémiai ciklus játssza a termosztát szerepét. A hőmérséklet növekedésével nő azoknak a reakcióknak a sebessége, amelyek széndioxidot vonnak ki a légkörből, ezáltal csökkentik az üvegházhatást és csökken a légkör hőmérséklete.

\section{Ember és természet, fenntarthatóság}

Összetett rendszerek általában alrendszerekre bonthatók, az alrendszerek ismét további alrendszerekre. Végül eljutunk a rendszer elemeihez, amelyek már nem bonthatók tovább.

$\mathrm{Az}$ ember a természet része. Az élettelen környezet (atmoszféra, hidroszféra, litoszféra) alrendszere az ökoszféra, amely magában foglalja a bioszférát. Az emberiség a bioszféra része, annak alrendszere (4. ábra). A rendszerelmélet szerint egy összetett rendszer zavartalan működésének feltétele, hogy a rendszer egésze és annak minden alrendszere azonos múködési stratégia szerint múködik (Gyulai, 2012). A társadalmi folyamatok azonban - különösen az ipari forradalom óta - a természettől idegen elvek szerint múködnek.
4. ábra: Az ember és a természet kapcsolata (forrás: a Szerző)

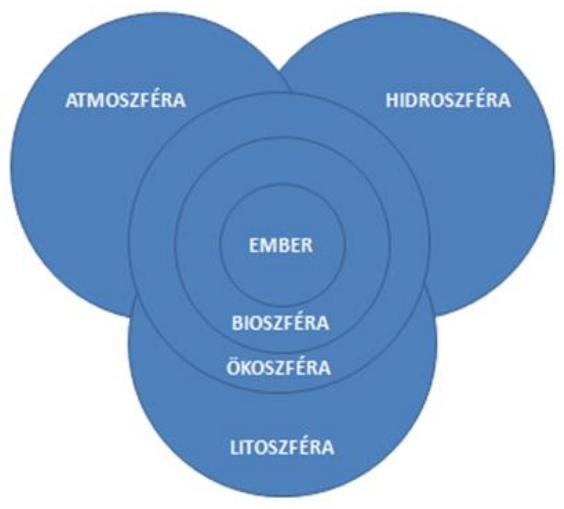

A természeti folyamatokra a szabályozás jellemző, vagyis az események visszahatnak a kiváltó okokra; a változásokat csökkenteni igyekszik a negatív visszacsatolás.

A társadalom - abban a tév-hitben, hogy az ember a természet fölött áll - sok esetben kiiktatja a természet szabályozó köreit és vezérlést valósít meg. Az ennek eredményeképp létrejött negatív hatásokat ellenhatásokkal igyekszik enyhíteni. Tipikus példa a hulladék kezelése: az ipari és egyéb tevékenységek során keletkezett óriási hulladéktömeg elhelyezése világméretű probléma.

Egyik „korszerü” módja a hulladékprobléma megoldásának a szemétégetők létesítése. A hulladék mennyisége ugyan ez által jelentősen csökken, de elégetésével a légkört szennyezzük. 
A természetben a legtöbb hulladék újra hasznosul, az ökoszisztémák anyagforgalma ciklikus. Az elpusztult növényi és állati maradványok a lebontó szervezetek működése folytán tápanyaggá válnak. Az ember termelő tevékenysége lineáris: a kiinduló anyagokból terméket állít elő, de közben nagy mennyiségű (többnyire használhatatlan) hulladék keletkezik. A hulladék újrahasznosításával a kört ciklikussá lehet tenni; az utóbbi évtizedek egyik sikertörténete a sok újrahasznosítási program. Az újrahasznosítás (a kör ciklikussá tétele) azonban rengeteg többlet energiát igényel (szállítás-feldolgozás), amelynek előállítása tovább növeli a környezet terhelését. A természet szabályozó mechanizmusának kiiktatására számos további példát lehet felhozni.

A természetes ökoszisztémák említett ciklikus jellege egyúttal korlátozza a hasznosítható tápanyag mennyiségét. A mezőgazdaság fejlődésével az ember képessé vált többlet-tápanyag (műtrágyák) bevitelére, ez által jelentősen megnőttek a terméshozamok (ez újabb példa a vezérlésre). A mellékhatás itt sem maradt el: a fokozott kemizálás eredménye a talajerózió, a savasodás és a termőképesség csökkenése. A termelés biztonságának növelésére a kártevők megfékezését peszticidek használatával biztosítjuk, ezek egy része viszont a táplálékba kerül és bennünket mérgez. A műtrágyák, a növényvédő szerek és a fokozott gépesítés együttese a „zöld forradalom” néven elhíresült fejlesztés, amely többszörösére növelte a terméshozamokat és nagymértékben hozzájárult a 20. századi népességrobbanáshoz.

Az emberiségnek több évezredes története során sokáig csak megújuló energia (nap-, víz-, szél-, geotermikus- és bioenergia) állt rendelkezésére. Ez korlátozta a fejlődés sebességét. A fosszilis energiahordozók (először a szén, majd az olaj és a földgáz) használatba vétele óriási ugrást jelentett. A jelentős többlet energia lehetôvé tette az ipar, a mezőgazdaság és a közlekedés addig soha nem látott iramú fejlesztését.

A gazdaságtörténészek becslése szerint (Chiras, 1994) a világgazdaság össztermelésének (a GWP-nek) megduplázódásához az ipari forradalom előtt több száz évre volt szükség. Az új erőforrások birtokbavételének köszönhetően a 20. században ehhez már csak 15-20 évre volt szükség. A felgyorsult fejlődésnek köszönhető a fogyasztói társadalom óriási árukínálata, de a népesség-robbanás, a környezetszennyezés és a klímaváltozás is. Nyilvánvaló, hogy ez a fejlődési ütem hosszú távon nem tartható az energiahordozók és a nyersanyagok véges készlete és - nem mellékesen - a környezet terhelése miatt.

Valószínű, hogy hosszabb távon a fosszilis energiahordozók készleteinek kimerülése miatt az ember ismét csak a megújuló energiát hasznosíthatja.

Akkor hát hogyan tovább? E komplex kérdéskör megválaszolásának igénye felvetette a fenntarthatóság problémáját, a- 
mely az utóbbi évtizedek egyik legjelentősebb interdiszciplináris kutatásának tárgya.

\section{A fogyasztói társadalom}

A hagyományos társadalmak fogyasztói szokásait a rendelkezésre álló áru mennyisége, és a szükségletek reális felmérése általában megfelelő módon szabályozta.

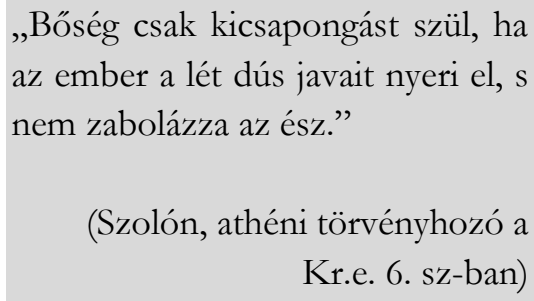

Továbbá az olyan józan megfontolások, mint például az, hogy „kell ez nekem?”, vagy „megengedhetem ezt magamnak?” visszacsatolást létesítettek az igény (a rendszer bemenete) felé és korlátozták a fogyasztást (5. ábra).

5. ábra: A szabályozás müködése a hagyományos társadalmak fogyasztási szokásaiban (forrás: a Szerzó)

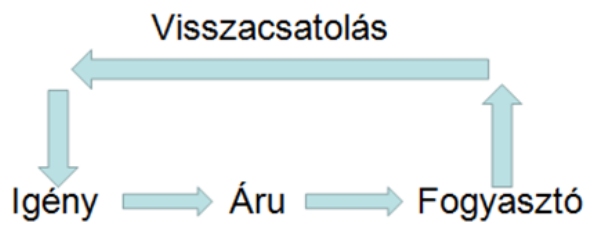

A fogyasztói társadalomban a szabályozást vezérlés váltotta fel (6. ábra). A fejlett ipari országokban kialakult piacgazdaság és a termelői oldal profitéhsége létrehozta azokat a túlhajszolt fogyasztási szokásokat, amelyeknek már semmi köze sincs a valódi igények kielégítéséhez.

6. ábra: A vezérlés a modern fogyasztói társadalomban (forrás: a Szerzó)

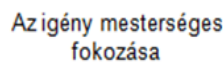

Valódi (vagyis megalapozott) igényeink mérlegelésekor ugyanis - normális esetben - múködik a már említett negatív visszacsatolás. A modern kereskedem azonban a maga kifinomult eszközeivel mindent megtesz, hogy a vásárlási szándékot a végletekig fokozza, a józan megfontolást (a Szolón említette „észzabolát”) pedig hatástalanítsa: erre szolgál a reklámok, hirdetések arzenálja, a „dobd el és vegyél újat" elv állandóan visszatérő refrénje, a félrevezető hitelcsábítások: „már nulla forintért a tiéd lehet” stb. Másrészt a termékekbe beépített gyors tönkremenetel, vagy gyors technikai elavulás sok esetben kikényszeríti az újabb vásárlást még akkor is, ha a fogyasztónál múködik a józan megfontolás. 


\section{Képzőmüvészet}

\section{- amikor a műalkotás is áruvá válik}

A 20. század elején a képzőművészetben viharos gyorsasággal bukkantak fel új irányzatok (,izmusok”), majd egyesek ugyanolyan gyorsasággal eltűntek, a folyamatot az állandó változás jellemezte (Read, 1965). Az izmusok többsége radikális, forradalmi nézeteket vallott, elutasította a korábban domináns klasszicista, akadémikus múvészeti irányokat, sőt még a többi izmust is és merőben új utakat keresett. Így jött létre, nagyjából időrendben, a „permanens forradalom” időszakában a fauvizmus, kubizmus, futurizmus, szürrealizmus, konstruktivizmus, az absztrakció és a dada. A korszak nagyjából 1930-ig tartott és utólag „,avantgárd korszak" néven vonult be a múvészettörténetbe.

A folytonos útkeresés, az állandó változás és az avantgárd radikálisabb képviselőinek nyilatkozatai nem mindig váltották ki a kortársak tetszését. Az avantgárd fénykorának vége felé (1924-ben) a helyzetet így értékeli a kor neves angol társadalomfilozófusa, Collingwood: „A tudományok fejlődésének tanulmányozásához hozzászokott történész szemében fájdalmas és nyugtalanító képet mutat a jelenkor múvészettörténete, mert úgy tűnik, hogy az nem előre, hanem visszafejlődik. A tudomány és a filozófia terén a tudósok folyamatos előrehaladást érnek el. A művészetben minden irányzat vagy iskola már alakulásának pillanatában a későbbi hanyatlás csíráit hordozza magában.
Amennyiben egyáltalán létezik megfigyelhető törvényszerűség az egyetemes művészet történetében, ez nem az előrehaladás, hanem a hanyatlás törvénye" (idézi: Read, 1965)

A művészi alkotás válságának gyökerei azonban ennél jóval mélyebbre nyúlnak vissza. Hegel esztétikai előadásaiban (Hegel, 1952) már 1820-ban foglalkozott ezzel a problémával: „Mai világunknak, vallásunknak és észműveltségünknek szelleme már túljutott azon a fokon, amelyen a múvészet az abszolútum tudatosításának legfőbb módja. A gondolat és a reflexió túlszárnyalta a szépművészetet... A múvészet már nem adja meg a szellemi szükségleteknek azt a kielégülést, amelyet a régebbi korok és népek csakis benne találtak meg. A görög múvészet szép napjai csakúgy, mint a kései középkor aranykora, elmúltak. Mindezen vonatkozásban a mûvészet - legmagasabb rendű meghatározása szemszögéből nézve - számunkra a múlté és azé is marad."

Már Hegel is érinti a művészet újkori válságának okait, de a 20. század második felére a kép teljesen letisztult és a válságot gyakorlatilag két fő okra vezették vissza. Németh (1999) szerint a két fó ok: megváltozott a „külső determináció” és a „preformáció” jellege. Mit is jelent ez? A korábbi korszakokat tekintve szembeötlő a társadalom részéről jött igény a műalkotásokra („külső determináció”). A kultikus barlangfestmények alkotói, a középkori miniátorok, a templomi freskófestők, a monarchiák udvari művészei, a holland 
portré- és zsánerkép-festők, mind külső (társadalmi) igényt elégítettek ki. Ezzel szemben „A modern művészet egyik alapvonása, hogy hiányzik a társadalomhoz való szilárd kötődése.

Egy évszázad óta egyre érezhetőbb, hogy a szellemi alkotók önmagukba húzódnak vissza. A világtól nem jön semmiféle feladat, amely megkötné őket. Saját felelősségükre önmaguknak kell megadni a feladatot is." - írja Karl Jaspers, 1933-ban (idézi Németh, 1999).

Mit jelent a „preformáció” (szó szerint: „előre megformáltság”)? A régebbi korokban egy „kollektív látásmód” határozta meg a művészi kifejezést, a „másképptenni-nem-tudás”, vagyis a korra jellemző stílus, amely még a legnagyobb mûvészekre is úgyszólván kötelező jelleggel bírt.

Ennek megfelelően beszélünk stíluskorszakokról, mint például reneszánsz, barokk, szecesszió stb. Goldbeck (1974) találó megjegyzése szerint a klasszikus zene korszakában „Mozart úgy komponál, mint Cherubini plusz zsenialitás, Cherubini úgy komponál, mint Mozart mínusz zsenialitás.” Hasonlóan elmondhatjuk a festészetben, hogy Rembrandt úgy fest, mint Esias van de Velde plusz zsenialitás, Esias van de Velde úgy fest, mint Rembrandt mínusz zsenialitás. A 20. sz. elejére azonban a korábbi stílusok már idejétmúlt régiségekké váltak, lázas stíluskeresés indult, ennek köszönhető az avantgárdban egymást viharos gyorsasággal váltó ,izmusok” sora.
A régebbi korokban a múalkotások a fentiek értelmében társadalmi igény hatására jöttek létre (7. ábra).

7. ábra: A müalkotások forgalmának hagyományos rendszere (forrás: a Szerző)

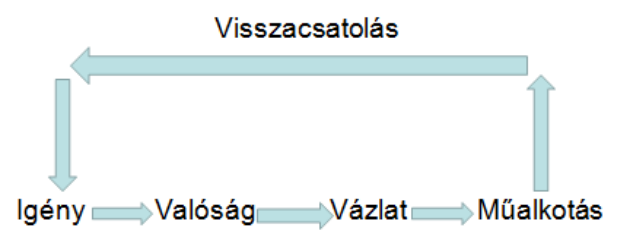

A megrendelő és a múvész között egyfajta munkáltató-munkavállaló viszony alakult ki, a múvész vázlatokat készített (többnyire valóságos vizuális élmények alapján), ezekből a megrendelő a neki legmegfelelőbbet kiválasztotta, ennek alapján elkészült a műalkotás. Innen azonban mindig volt egy visszacsatolás: a megrendelő vagy elfogadta a kész művet, vagy változtatásokat kért; a végleges forma egy szoros együttműködési folyamat révén alakult ki.

A folyamat tehát egy zárt hatásláncú, szabályozott rendszerrel rokonítható. A festészet (és a szobrászat) legnagyobb remekművei (még Leonardo főművei, vagy Michelangelo Sixtus kápolna freskói) is ilyen együttműködési folyamat révén jöttek létre. Megjegyzendő, hogy a külső determináció bizonyos fokig a stílust (a preformációt) is meghatározta: a műalkotás formailag nem térhetett el túlzottan a kor stílusától, szélsőséges kilengéseket a 
megrendelő nem tűrt volna el. A stíluskorszakok között a változás igen lassú folyamat volt és többnyire (itt nem részletezett) társadalmi változások következménye volt.

A 20. század elejére azonban a műalkotások iránti társadalmi igény lecsökkent, a művészek egzisztenciája kétségessé vált. Külső determináció híján maguk kerestek új tartalmakat és formákat alkotásaikhoz. Szabad kezet kaptak tehát minden tekintetben, de ez a szabadság egyúttal rendkívüli nehézségekkel járt. Fülep Lajos 1905-ben így jellemezte a modernkori művészek helyzetét: „Nézzétek, egy fölfelé törő vonal, alatta nincs, amire támaszkodjék, ahova fönt kapcsolódni akar, nem éri el. Lóg a levegőben és nem marad számára más, mint hogy erre a levegőben lógó vonalra, mely egyszerre a kezdet és a vég, erre építsen, mindenkitől külön, kizárólag magára, egy voltára, egyéni voltára."

Kandinszkij, az absztrakt festészet egyik reprezentánsa 1910-ben (Read, 1965) a 8. ábrán látható módon határozta meg a festő alkotási folyamatát.

8. ábra: A müalkotás létrejöttének folyamata Kandinszkij szerint (forrás: a S zerzö)

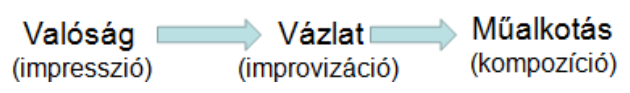

A folyamatból feltűnő módon hiányzik a „külső determináció”, a társadalmi igény. A múvész szubjektivitása meghatározó a mű létrejöttében. Kétségtelen, hogy a művész szabadsága itt jóval nagyobb, mint az előző korszakokban, nem kötik meg a kezét a megrendelő elvárásai, de ugyanakkor megnőtt az egész alkotási folyamat esetlegessége. A 9. ábrán néhány jellegzetes műalkotás segítségével megkíséreljük bemutatni az absztrakció kialakulásának folyamatát.

A fogyasztói társadalomban a műalkotások is áruvá váltak, a művészet meggyengült társadalmi státusza miatt azonban árupiaci forgalmuk ingataggá vált. Mind az igény, mind a fogyasztó megléte bizonytalanná vált ebben a folyamatban.

A fejlődés bizonyos fokán aztán egyes üzleti körök kiszimatolták az ágazatban rejlő profit-lehetőségeket és országonként változó időpontban, de mindenütt megjelent a múkereskedelem. A műalkotások forgalma ezzel a legtöbb helyen felpezsdült. A műkereskedelem azonban - a fogyasztói társadalom rendjének megfelelően - egy mesterségesen felfokozott igényt gerjeszt. Kitűnő jellemzést ad a jelenlegi helyzetről Gombrich (1974): „A közönség mindent befogad, lelkes képviselői - kurátorok, múzeumigazgatók, művészettanárok, képkereskedők - lázas sietséggel szervezik a kiállításokat, magyarázó cédulákat tűznek a műalkotásokra, mielőtt megszáradna a festék, vagy megszilárdulna a szobrok anyaga. Az egymással összedolgozó kritikusok, mint valami 
(1)

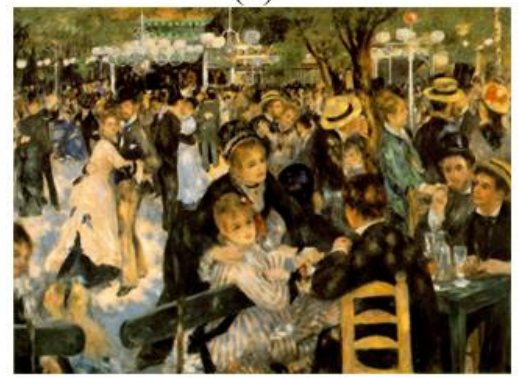

(2)

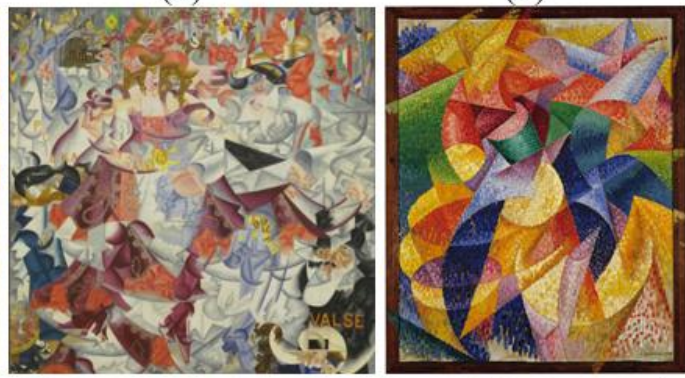

(4)
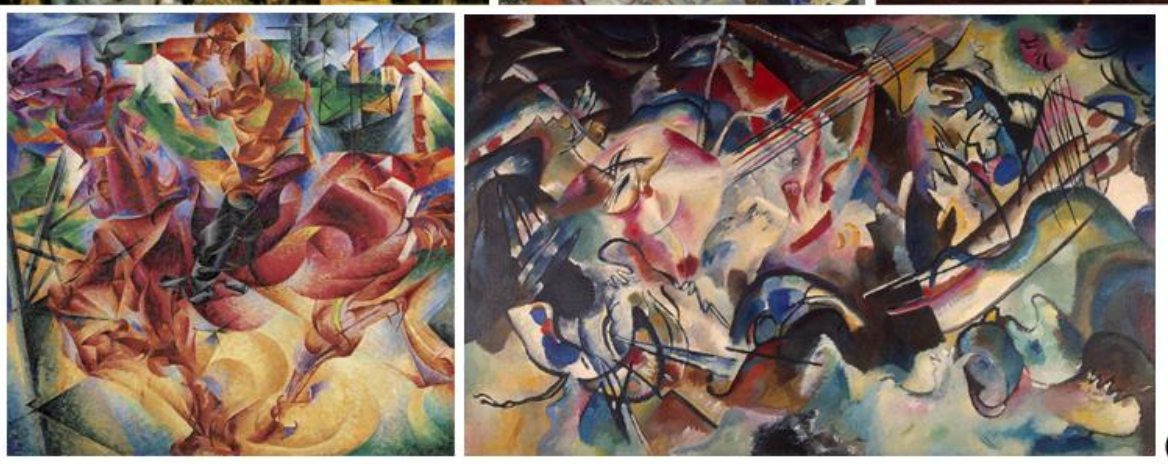

(5)

Megjegyzés: Az (1) kép: Renoir kerti táncmulatsága, ábrázolásmódja még konvencionális; a (2) kép: Severini bárjelenete; itt már csak sejteni lehet egy táncos forgatag hullámzását, de még utalások vannak a táncstílusokra: VALSE és POLKA, továbbá két alak: egy lovas és egy ollón lovagló akt utal a tánc dinamizmusára és a jelenet erotikus jellegére; a (3) kép: Severini táncosnője már csak a tánc dinamizmusát érzékelteti, a (4) kép Boccioni: Elasticity és az (5) kép Kandinszkij: Kompozíció III, már nem tartalmaz hagyományosan értelmezhető információt.

felderítő csoport tagjai, végigfésülik a műtermeket készen arra, hogy lecsapjanak a jövő mûvészetére és vezetô szerepet vállaljanak népszerűsítésében. A művészettörténészek fényképezőgéppel, jegyzettömbbel állnak lesben, nehogy elmulasszanak egyetlen újszerű részletet. Az 'újszerü' tradíciója minden más tradíciót közhellyé fokozott le." A műalkotások forgalmának modernkori rendszere tehát a korábbi szabályozott rendszerből a fogyasztói társadalomra jellemző vezérelt rendszerré (10. ábra) alakult. Fontos megemlíteni, hogy múkereskedelem már a 
10. ábra: A modernkori mükereskedelem vezérelt rendszere (forrás: a Szuerző)

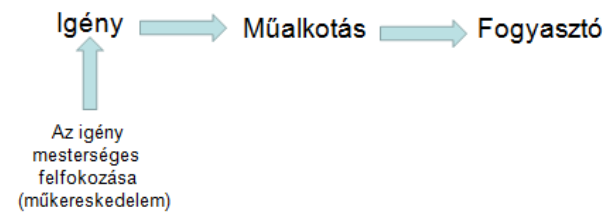

17. században is volt, sőt aukciókról is vannak beszámolók már az 1600-as évek elejérôl. Domináns tényezővé azonban csak a 19-20. században, a piacgazdaság terjedésével vált.

Az újdonság állandó hajszolása gyakran elsiklik a valódi értékek mellett. A valódi közösségi indíttatás helyett a művészek egy része a divathóbortok hálójába kerül. Akik nem hajlandók magukat alávetni a múkereskedelem által diktált igényeknek, azok (többnyire az elhivatott, igényes alkotók) állandó egzisztenciális problémákkal küzdenek.

A műpártolók, műértők tábora fogyasztóvá degradálódik. Az újdonságért való állandó versenyfutás miatt nincs lehetőség valódi stílusjegyek kiérlelésére. Kováts Albert festőművész 2005. évi kiállítási ismertetőjének panasza feltűnően összecseng Fülep Lajos fentebb idézett pontosan száz évvel korábban megállapított pontos diagnózisával: „Manapság nem látok semmit a világban, ami iránymutatóul szolgálna életre és művészetre. Nincs irány, nincs biztos pont. Az ember, a múvész csak önmagára számíthat. Ez reménytelenül kevés és végtelenül sok. Ebben áll a mai művészet nehézsége."

\section{Természettudomány}

A modern tudomány múvelőinek nem kellett a művészekhez hasonló társadalmi izolációt elszenvedni. Természetesen a tudósoknak is voltak egzisztenciális problémáik (egy klasszikus példa: Keplernek is vállalnia kellett a szellemi prostitúciót horoszkópok készítését - amint ezt Madách, a Tragédia prágai jelenetében oly meghatóan ábrázolja). A tudomány felé azonban minden korszakban meg volt a társadalmi igény, sőt az ipari forradalom, a technika felgyorsult fejlődése óta az igény állandóan nőtt.

A múvészet 20. századi forradalmával egy időben természettudományos forradalom is végbement (Simonyi, 1998). Max Planck a 19. sz. utolsó éveiben a magas hőmérsékletű (izzó) testek sugárzását vizsgálta; erre mindaddig csak részleges fizikai magyarázatok voltak, a fizikusok nem tudták világosan értelmezni a tapasztalati tényeket. Planck 1900-ban végül megoldotta a problémát: sikerült egy általános, minden vonatkozásban kielégítő magyarázatot adni a sugárzásra, de csak azzal a - saját maga által is kételkedve fogadott - feltételezéssel, hogy a sugárzást létrehozó részecskék (akkor még nem tudták, mik ezek a részecskék) energiája nem folytonosan, hanem csak meghatározott értékekkel - kvantumokkal változhat. Ez a feltételezés (a kvantum- 
hipotézis) a klasszikus fizikától teljesen idegen volt, a testek energiája a mindennapi tapasztalat számára hozzáférhető (makro-)világban folytonosan változhat. Planck feltevésének helyessége később bizonyságot nyert, megszületett a kvantumelmélet, sőt ma már az egész modern fizika születését innen számítjuk.

A kvantumhipotézis rendkívül termékenynek bizonyult, alkalmazásával sikerült a fényelektromos hatásra kielégítő magyarázatot adni (Einstein) és kidolgozni az első jól megalapozott atommodellt (lásd:
Bohr). A mozgó testek elektrodinamikájának beható vizsgálata nyomán dolgozta ki Einstein a relativitáselméletet, amely teljesen új megvilágításba helyezte a tér és idő hagyományosan abszolútnak tekintett fogalmait (a newtoni tér-idő fogalmat). Heisenberg határozatlansági relációi (Simonyi, 1998) a mikrovilágban objektív módon meglévő - a dolog belső természetéből fakadó - bizonytalanságra világítottak rá, ezáltal a klasszikus tudomány szigorú determinizmuson alapuló világszemlélete rendült meg (11. ábra).

\section{1. ábra: A klasszikus és a modern fizikea nébány kiemelkedö eredménye (forrás: a Szuerōô)}

\section{KLASSZIKUS FIZIKA}

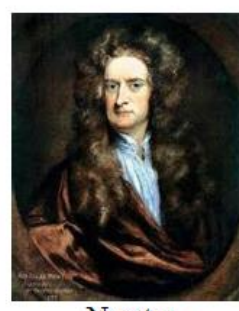

Newton

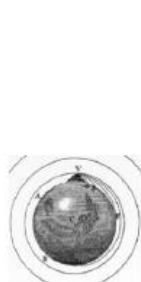

gravitáció

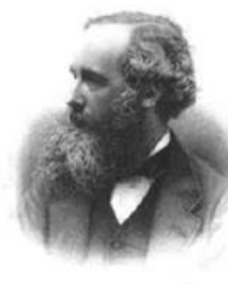

Maxwell

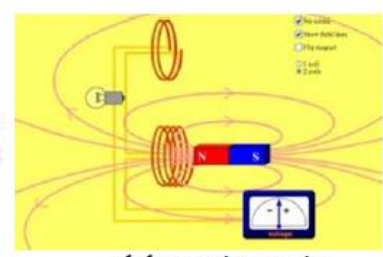

elektromágnesség

MODERN FIZIKA

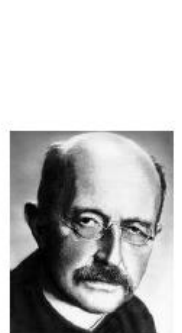

Planck

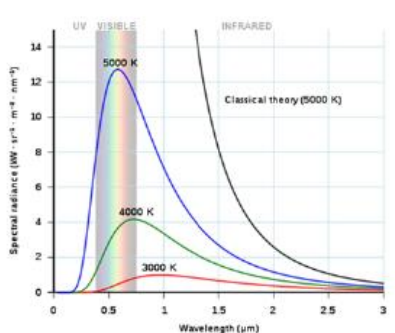

kvantumhipotézis

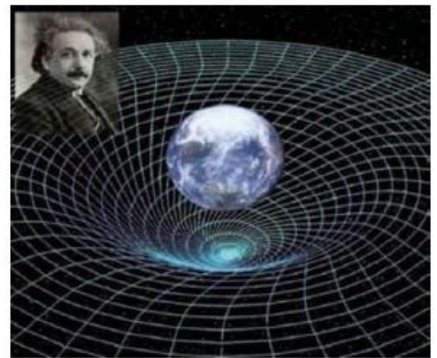

Einstein - relativitáselmélet 
A modern tudományban tehát a 20 . sz. első felében az előbb röviden vázolt forradalmian új felismerések születtek, a klasszikus fizika helyett (vagy inkább mellette) egy teljesen új, modern fizika jött létre, amely lassan széles körben elfogadottá vált.

Heisenberg, aki művészeti kérdésekkel is foglalkozott, egy 1920-ban lezajlott beszélgetést idézve ezt írja (Heisenberg, 1978): „A kifejezendő tartalom és a korlátozott kifejező közeg közötti kölcsönhatás - vagy küzdelem - a valódi művészet sine non qua-ja (elengedhetetlen feltétele). Ha megszüntetjük a közvetítő közeg korlátozottságát - ha a zenében például tetszés szerinti hangokat, hangsorokat képezhetünk, akkor vége a harcnak: a múvész légüres térben küszködik. Ezért én szkeptikus vagyok a túlzott szabadsággal szemben. (...) A modern tudomány tisztán megfogalmazza kérdéseit; megtalálni a helyes válaszokat, ez a pontosan körülhatárolható feladat. A modern művészetben viszont még maguk a kérdések is bizonytalanok." Goethe Természet és müvészet c. szonettjében már másfél évszázaddal korábban figyelmeztetett a túlzott szabadság veszélyeire:

„Ez minden alkotás belső szabálya:

Ki nagyot akar, magát zabolázza, korlátozásban tünik ki a mester s csak törvény adhat szabadságot nekünk."

(Rónay György fordítása)
$\mathrm{Az}$ avantgárd művészei azonban nyílvánvalóan a korlátlan múvészi szabadság hívei voltak. A mozgalom alapelvei: a tiltakozás és a múlt lerombolása, nem hozhattak létre maradandó műalkotásokat. Ennek ad hangot Collingwood is a korábbi idézetben, de a tiszavirág életú „,izmusok” gyors tündöklése és bukása is ezt látszik igazolni.

Másrészt viszont a modern tudomány fontos, új eredményei közül egyik sem vált érvénytelenné, hanem a természetről szerzett tudásunk fontos részévé vált. A különbség minden bizonnyal a két alkotói módszer, valamint a természettudós és a művész szabadságának minőségi különbségéből ered.

A természetkutató vizsgálódása közben mindig szembesül a tapasztalat kritikájával; csak azok a hipotézisek, felismerések, elméletek (modellek) válnak érvényessé, amelyeket a tapasztalat (megfigyelés, vagy kísérlet) kétséget kizáróan igazol. Ha ez nem teljesül, más utakon kell a probléma megoldását keresni mindaddig, amíg a tapasztalattal egyező eredmények születnek (12. ábra).

12. ábra: A tudományos kutatás szabályozott (visszacsatolt) rendszere (forrás: a Szerzố)

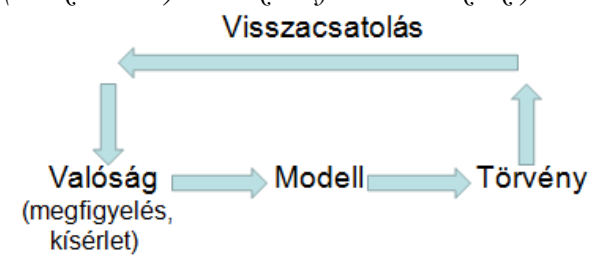




\section{Zárógondolatok}

Az új elméletek, modellek legtöbbször nem helyezik hatályon kívül a régieket, csak meghatározzák (korlátozzák) azok érvényességi tartományát. Például a relativitáselmélet nem érvénytelenítette a newtoni (klasszikus) fizikát, csak az újabb tapasztalatok figyelembevételével kijelölte érvényességének határait. A művészek modernkori korlátlan alkotói szabadságával szemben a kutatói szabadság minden történeti korban korlátozott volt: a tapasztalattal való feltétlen egyezés követelménye szigorúan megszabta korlátait.

\section{Irodalom}

Bárczi G. és Országh L. (szerk.)(1989): $A$ magyar nyelv értelmezó szótára. Akadémiai Kiadó, Budapest.

Chiras, D. (1994): Environmental Science. New York: Benjamin/Cummings.
Fülep L. (2001): Európai müvészet - Magyar müvészet. Kriterion, Kolozsvár.

Goldbeck, F. (1974): A tökéletes karmester. Zenemúkiadó, Budapest.

Gombrich, E. H. (1974): A müvészet története. Gondolat, Budapest.

Gyulai I. (2012): A fenntartható fejlödés. Ökológiai Intézet, Miskolc.

Hegel, G.W.F. (1952): Esztétikai elóadások. Akadémiai Kiadó, Budapest.

Heisenberg, W. (1978) A rész és az egész. Gondolat, Budapest.

Lorenz, K. (2001): A civilizált emberiség nyolc balálos büne. Cartaphilus, Budapest.

Németh L. (1999): A müvészet sorsfordulója. Ciceró Kiadó, Budapest.

Read, H. (1965): A modern festészet. Corvina, Budapest.

Simonyi K. (1998): A fizika kultúrtörténete. Akadémiai Kiadó, Budapest.

Szűcs E. (1999): Rendszer és modell. Tankönyvkiadó, Budapest. 